\title{
Madeleine Tyssens, "La Tierce geste qui molt fist a prisier". Études sur le cycle des Narbonnais
}

\section{Walter Meliga}

\section{(2) OpenEdition}

1 Journals

\section{Edizione digitale}

URL: http://journals.openedition.org/studifrancesi/319

DOI: 10.4000/studifrancesi.319

ISSN: 2421-5856

\section{Editore}

Rosenberg \& Sellier

\section{Edizione cartacea}

Data di pubblicazione: 1 aprile 2015

Paginazione: 121

ISSN: 0039-2944

\section{Notizia bibliografica digitale}

Walter Meliga, "Madeleine Tyssens, "La Tierce geste qui molt fist a prisier". Études sur le cycle des Narbonnais », Studi Francesi [Online], 175 (LIX | I) | 2015, online dal 01 avril 2015, consultato il 18 septembre 2020. URL : http://journals.openedition.org/studifrancesi/319; DOI : https://doi.org/ 10.4000/studifrancesi.319

Questo documento è stato generato automaticamente il 18 settembre 2020.

\section{(c) $(1) \ominus$}

Studi Francesi è distribuita con Licenza Creative Commons Attribuzione - Non commerciale - Non opere derivate 4.0 Internazionale. 


\title{
Madeleine Tyssens, "La Tierce geste qui molt fist a prisier". Études sur le cycle des Narbonnais
}

\author{
Walter Meliga
}

\section{NOTIZIA}

MADELEINE TYSSENS, "La Tierce geste qui molt fist a prisier". Études sur le cycle des Narbonnais, Paris, Classiques Garnier, 2011 («Recherches littéraires médiévales», 9), pp. 239.

1 Il volume è una raccolta di dodici saggi già editi, e per lo più dispersi o di difficile reperibilità, sul cosiddetto cycle des Narbonnais o di Garin de Monglane (secondo la celebre tripartizione delle chansons de geste operata da Bertran de Bar-sur-Aube, e ripresa nel titolo del libro) scritti dalla celebre specialista dell'epica francese, che proprio alla geste dei Narbonesi ha dedicato molti altri studi e un importante saggio sulle canzoni che hanno Guglielmo d'Orange come protagonista. Di questo ampio lavoro una dettagliata bibliografia alle pp. 9-11 fornisce le coordinate bibliografiche.

2 In particolare, sono presenti nella raccolta alcuni notevoli articoli sulla questione dell'oralità dell'epica in rapporto da una parte ai giullari e ai copisti e dall'altra alla pratica editoriale che rappresentano una parte molto rilevante della discussione critica su questi argomenti. 